Egyptian J. Anim. Prod. (2012) 49(2):207-217

\title{
NUTRITIVE VALUE OF SKIMMED MILK AND WHEY, ADDED AS NATURAL PROBIOTICS IN BROILER DIETS
}

\section{I.I. Omara}

Division of Poultry Nutrition, Department of Animal Production, Faculty of Agriculture, Cairo University, Giza, Egypt

\section{SUMMARY}

Present study investigated the effect of adding either commercial or natural probiotics to broilers diets on growth performance, nutrients digestibility and economical efficiency. Avi-Bac (a probiotic product of concentrated lactic acid bacteria and enzymes) was used as a commercial probiotic, while fresh skimmed milk and whey were used as a natural probiotics.

Nine hundred one-day-old unsexed Hubbard broiler chicks were randomly distributed into 6 experimental groups, of 150 broilers, with 3 replicates for each treatment group.

All diets were formulated to contain the tested levels of both commercial and natural probiotics and were fed in a mash form. The experimental diets were fed in 2 phases: grower (1-4 wk) and finisher (5-6 wk). Avi-Bac was used at level of 0.1\%, while skimmed milk or whey were added at levels of 0.5 or $1.0 \%$ of the diet. Water and feed were offered ad-libitum throughout the experimental period, which lasted 6-weeks.

Broilers receiving the diets supplemented with commercial and natural probiotics showed significantly $(P<0.05)$ improved growth performance including body weight, body weight gain, feed intake and feed conversion ratio (FCR) compared with those fed the basal diet (control). Broilers fed $1 \%$ whey diet consumed more feed $(P<0.05)$ and had greater body weight gain than the control group. Feed/gain ratio improved significantly $(P<0.05)$ with $1 \%$ whey diet compared with the control. The digestibilities of organic matter (OM), crude protein (CP), ether extract (EE) and nitrogen free extract (NFE) and nitrogen balance increased with $1 \%$ whey supplementation. However, there was no significant difference $(P>0.05)$ in crude fiber digestibility. Also, the data showed that adding both natural or commercial probiotics to broiler diets improved the average values of calculated economical efficiency.

The obtained results indicated that natural or commercial probiotic can be used as a growth promoter in broiler diets and it can improve performance, nutrient digestibility and economic efficiency of broilers.

\section{Keywords: Probiotic, skimmed milk, whey, broilers, performance, digestibility}

\section{INTRODUCTION}

In poultry industry, antibiotics are used worldwide with the objective of improving growth performance and prevention of diseases. However, repeated use of antibiotics in poultry diets resulted in severe problems like resistance of pathogen to antibiotics, accumulation of antibiotics residue in animal products and environment, imbalance of normal microflora, and reduction in beneficial intestinal microflora (Barton, 2000). These concerns resulted in severe restriction or total ban on the use of antibiotics in animal and poultry industry in many countries. As a result, the poultry industry must focus on alternative to antibiotics for maintaining health and performance under commercial conditions.

Probiotics refer to a group of nonpathogenic organisms that, when administered in sufficient amount, are known to have beneficial effects on health of the host
(Mountzouris, et al., 2007). Several studies reported beneficial effect of probiotics on growth performance (Kim et al., 2011), nutrient retention (Shim et al., 2010), gut health (Awad et al., 2010), intestinal microflora (Mountzouris et al., 2010), reduced the susceptibility to diseases (Mulder et al., 1997), enhanced immunity function (Molnár et al., 2011), and improved carcass yield and quality in poultry (Bielecka et al., 2010).

Probiotics used in broilers include Lactobacillus, Bifidobacterium, Bacillus, Streptococcus, Pediociccus, Enterococcus, and yeast such as Saccharomyces cerevisiae and Saccharomyces boulardii (Kabir, 2009). While the functionality of probiotics depends on their ability to survive and colonize the gastrointestinal tract, the resistance of cells to bile acids is a property that is necessary (Taranto et al., 2006). However, many studies have indicated that probiotic bacteria may not survive in sufficient numbers when they pass

Issued by The Egyptian Society of Animal Production 
through the gastrointestinal tract in in-vitro test (Maragkoudakis et al., 2006). It was proposed that the consumption of live microorganisms (mainly lactic acid bacteria) could improve intestinal health and the well-being of the host (Li et al., 2008).

Skimmed milk was used as the suspension medium because of its strong effect on the stability of probiotic bacteria (Sodini et al., 2002). It showed that broiler chicks can be fed on Lactobacillus bulgaricus strain from skimmed milk as a growth promoter to improve performance, nutrient digestibility and antibody production under hot and humid conditions which prevail in the tropics (Apata, 2008).

Whey, the liquid remaining from cheese or manufacturing and casein production, is one of the most valuable protein sources in human food chain. In spite of its balanced nutrients, liquid whey is disposed of as a waste product, leading to environmental pollution, which is of great concern in many counties (Thivend, 1977). Also, whey is produced in the process of milk acidification. Lactic acid bacteria breaks down lactose (milk sugar) into glucose and galactose, and then glucose is converted to $\mathrm{L}(+)$ lactic acid during lactic acid fermentation (Pijanowski, 1984).

It follows that both the level and form of whey supplementation may significantly affect broiler performance. Adding whey to diets resulted in linear increase in body weight gain and nitrogen retention in broiler chickens (Kermanshahi and Rostami, 2006), and significantly improved digestibility of protein and fat, feed to gain ratio, and increased absorption of minerals like, $\mathrm{Ca}, \mathrm{P}, \mathrm{Cu}, \mathrm{Fe}$ and $\mathrm{Mg}$ (Cleaves and Salim, 1982).

The purpose of the present study was to investigate the effect of adding commercial probiotic (Avi-Bac) or natural probiotics (skimmed milk or whey) in broiler diets on growth performance, nutrient digestibilities, nitrogen retention and economical efficiency of broiler chicks.

\section{MATERIALS AND METHODS}

The study was conducted at the Experimental Station of the Animal Production Department, Faculty of Agriculture, Cairo University. A total number of 900, one-dayold, unsexed Hubbard broiler chicks, of nearly similar live body weight $(45 \mathrm{~g})$ were used to study the effect of adding either commercial or natural probiotics on performance, nutrients digestibility and economical efficiency. AviBac was used as a commercial probiotic, while fresh skimmed milk and whey were used as a natural probiotics (Dairy Technology Unit, Faculty of Agriculture, Cairo University -
Price free). Avi-Bac is a probiotic product of concentrated lactic acid bacteria and enzymes for use in poultry diets. Each gram of Avi-Bac contains 1.6 billion CFU lactic acid bacteria (ProByn International Inc.).

Birds were randomly assigned to 6treatments; each contained 150-birds in three replicates. Chicks were allocated in a littered floor poultry house in an open system under the same management conditions. Water and feed were offered ad-libitum and artificial lighting was provided 24-hours daily throughout the 6-weeks experimental period. All diets were formulated to contain the tested levels of both commercial and natural probiotics and were fed in mash form. Avi-Bac was used at level of $0.1 \%$, while both skimmed milk or whey were added at levels of 0.5 or $1.0 \%$ of the diet. Accordingly, there were 5experimental treatments plus a control diet as shown in Tables 1 and 2.

Vitamins, minerals and amino acids were added to cover the recommended requirements of broiler chicks according to the strain guidelines. Formulation of the experimental diets and their chemical composition are presented in Tables 1 and 2 .

Live body weight (BW) and feed intake were recorded during the grower (1- 4 week) and finisher (5-6 week) periods. Body weight gain (BWG) and feed conversion ratio (FCR) were calculated for the same periods. At the end of the 42-day of age, 9-chicks from each treatment were chosen and randomly housed individually in metabolic cages to determine digestibility coefficients of nutrients.

Analysis of feed and dried excreta was done according to the official methods of A.O.A.C (1990). Nitrogen-free extract was calculated according to Abou-Raya and Galal (1971). Fecal nitrogen was determined according to Jakobsen et al. (1960). Finally, all treatments were economically evaluated as total cost needed to obtain one kilogram body weight and the net revenue per unit of total cost.

All dada were subjected to a one-way analysis of variance using SAS programme (SAS, 2004). Variables having significant differences $(\mathrm{P}<0.05)$ were compared using Duncan's multiple range test (Duncan, 1955).

\section{RESULTS AND DISCUSSION}

\section{Broiler performance: \\ Body weight and body weight gain:}

Effects of experimental treatments on body weight and body weight gain were significant $(\mathrm{P}<0.05)$ at the end of grower and finisher periods (Table 3). Body weight, at the beginning of the experiment, did not significantly vary among groups $(\mathrm{P}>0.05)$. 
Compared with the control, probiotic supplementation (Avi-Bac, skimmed milk or whey) significantly improved body weight and body weight gain during the grower, finisher, and overall periods. The group that received $1 \%$ whey $\left(\mathrm{T}_{6}\right)$ recorded the best body weight and body weight gain in grower, finisher, and overall periods. Improvement in body weight gain due to feeding of $1 \%$ whey was $16,14.60$ and $15.24 \%$ at grower, finisher and overall periods, respectively. However, there was no significant difference $(\mathrm{P}>0.05)$ in body weight and body weight gain at the end of each period among dietary treatments $\left(\mathrm{T}_{2}, \mathrm{~T}_{3}, \mathrm{~T}_{4}\right.$ and $\left.\mathrm{T}_{5}\right)$ which fed on diets supplemented with probiotics. These results agreed with those of Shim et al., (2010), Wang and Gu (2010), and Kim et al. (2011), who concluded that adding probiotic (Lactobacillus) to broilers diet caused a significant improvement in their weight.

In general, data on growth response showed that Lactobacillus (LB) from skimmed milk produced significant improvements over the control group. These observations confirmed previous findings that dietary supplementation with LB cultures improved the performance of chickens (Apata, 2008). The enhanced growth with LB may be partly attributed to the colonization of the gastrointestinal tract of the chicks, which improved the digestion of essential nutrients. However, it is known that nutrients, especially protein, metabolized by microflora are not utilized by the host. Thus it possible that skimmed milk usage as a medium to ensure stability of the probiotic might have stimulated proteolytic or protein digestion activity, thereby contributing to the improvement in nutrient digestion.

Birds offered whey in diets from 2-weeks of age, performed better, and had significantly greater body weight $(\mathrm{P}<0.05)$ compared to control, and birds offered whey as drinking liquid (Shariatmadari and Forbes, 2005). Whey has been known to be a source of unidentified factor (UGF) and is routinely used in poultry diets (Susmel et al., 1995). Researchers attributed the UGF of whey to its balanced amino acids (Al-Ubaidi and Bird, 1964), high protein efficiency ratio (Susmel et al., 1995), rich source of water soluble vitamins and minerals (Modler, 1982), and increased lactase enzymes which is lacking in poultry digestive system (Glusen et al., 2002). Ahmad (2006) used whey as a substitute of antibiotics in considerable amounts and as growth promoters in broilers production. Wang and Gu (2010) showed that probiotic administration in feed at a certain concentration displayed a growth promoting effect and increased activities of protease and amylase. Based on these results, use of a probiotic supplement in broilers diet was recommended to stimulate productive performance. Growth rate tended to increase with dried whey supplementation, however it should be noted that this numerical increase in growth rate might have been influenced by the relatively higher feed intake (Samli et al., 2007).

\section{Feed intake and feed conversion ratio:}

Birds fed diets supplemented with Avi-Bac, skimmed milk and whey showed higher feed intake and better FCR during grower (1-4 week), finisher (5-6 week), and throughout the study period (1-6 week) compared to control, as shown in Table 3. During grower phase, feed intake of broilers in treatments $\mathrm{T}_{3}$ and $\mathrm{T}_{4}$ were greater $(\mathrm{P}<0.05)$ compared with the control, but not different significantly between Avi-bac and whey treatments $\left(\mathrm{T}_{2}, \mathrm{~T}_{5}\right.$ and $\mathrm{T}_{6}$, respectively). As for $\mathrm{FCR}$, the probiotic supplementation $\left(\mathrm{T}_{2}\right.$ to $\left.\mathrm{T}_{6}\right)$ showed better value $(\mathrm{P}<0.05)$ than the control. Moreover, during finisher phase and overall periods, higher feed intake $(\mathrm{P}<0.05)$ and better FCR $(\mathrm{P}<0.05)$ were noticed in birds fed $1 \%$ whey than birds fed control diet.

Therefore, results from current study confirmed that supplementation commercial (Avi-Bac) and natural (skimmed milk and whey) probiotics in broiler diets improved feed intake and FCR. These results are in agreement with Khakesfidi and Ghoorchi (2006) who reported that inclusion of probiotic in broiler diets resulted in improvement in the average values of feed intake and FCR.

Improvement in growth performance and feed efficiency of broiler diets supplemented with different types of probiotics yielded cumulative effect of probiotic action including the improvement of feed intake and digestion (Shim et al., 2010), increased digestive enzyme activity and decreased ammonia production (Jin et al., 2000), maintained beneficial microbial population (Fuller, 1989), and caused an alteration gastrointestinal bacterial metabolism (Jin et al., 1997). All these changes could improve the efficiency of feed consumed by birds. Partial improvement might be related to the beneficial the effect of lactose on gut microorganisms like increased Lactobacillus and Bifidobacteria population in the gut of the chickens (Kermanshahi and Rostami, 2006). Apata (2008) noticed that feed intake and feed/gain ratio with the LBsupplemented from skimmed milk to broiler diets were significantly better than with the control diet. The addition of dried whey up to $1 \%$ to poultry diets showed greatest amount of feed intake $(\mathrm{P}<0.05)$ and improvement in FCR, 
due to increased presence of useful microbes in digestive system, which help to overcome harmful microbes. This would result in increased growth and FCR improvement (Radfar and Farhoomand, 2008; Aghaei et al., 2010).

Overall, the beneficial effects of using probiotics on broiler performance were in agreement with a larger number of published studies using probiotics in broilers (Willis and Reid, 2008), compared with studied that reported lack of positive effects (Priyankarage et al., 2003). However, it was difficult to directly assess different studies using probiotics, because the efficacy of any given probiotic application depends on many factors such as species composition and viability, administration level, application method, frequency of application, overall composition of diets used, bird age, overall farm management and hygiene, the quantity of probiotic used, and environmental stress factors.

\section{Nutrients digestibility:}

Birds fed diets supplemented with $1 \%$ whey $\left(\mathrm{T}_{6}\right)$ recorded highly improved $(\mathrm{P}<0.05)$ apparent digestibility of $\mathrm{OM}, \mathrm{CP}, \mathrm{EE}$ and nitrogen balance; whereas, no difference $(\mathrm{P}>0.05)$ was noted on digestibility of $\mathrm{CF}$ and NFE, compared with the control, as shown in Table 4. Moreover, digestibility of $\mathrm{CP}$ was higher in birds fed diets supplemented with commercial or natural probiotics than birds fed control diet. No significant differences were detected between birds fed Avi-Bac or 1\% whey on digestibility of OM, CP and NFE. These results were similar to the finding of $\mathrm{Li}$ et al. (2008) who found that feeding broilers on diets supplemented with probiotic enhanced the digestibilities of many nutrients. Also, there were some reports showing that addition of whey up to $4 \%$ of the diet increased fat and protein digestibility (Susmel et al., 1995) and increased absorption of some minerals, like calcium and phosphorus (Al-Ubaidi and Bird, 1964).

Probiotics showed beneficial effect on the host animal by improving its intestinal microbial balance (Fuller, 1989), through creating gut micro ecological conditions that suppress harmful microorganisms like Clostridium and Coliforms, and by favoring growth of beneficial microorganisms like Lactobacillus and Bifidobacterium (Shim et al., 2010; Kim et al., 2011). In line with previous findings, birds fed diets with added $B$. subtilis LS 1-2 had lower Clostridium and Coliform counts compared to control diet. Suppression of harmful microorganisms resulted in better growth and metabolism of beneficial microorganism which might have improved the growth performance and apparent nutrients retention in the current study. A number of previous studies have demonstrated the potential of probiotics in improving the beneficial bacteria and suppress potentially pathogenic bacteria in the intestine (Mountzouris et al., 2010). Also, these bacteria are beneficial for maintaining the integrity and function of the small intestine in the host bird (Jadamus, 2001), which then promotes absorption and transport of glucose, amino acids, $\mathrm{Ca}, \mathrm{P}$ and other nutrients across the intestinal epithelium into blood circulation.

The enzymes protease and amylase play an important role in the fermentation of relative nutrient, ultimately on animal performance and health. As a result, protein digestibility and utilization of diets with added probiotics would improve consequently. These results were similar to the finding reported by Jin et al. (2000) who reported that inclusion of a probiotic (a single strain of L. acidophilus or a mixture of 12 Lactobacillus strains) resulted in significantly higher amylase enzyme activities in the small intestine of broilers. The protease and amylase activities of broilers were also positively affected by the final concentrations of probiotic in the diet. The higher activity of protease and amylase improved the digestion of protein and starch, which might in turn explain the better growth observed in current study with $\mathrm{T}_{6}(1 \%$ Whey) diet.

Dietary LB from skimmed milk significantly increased the apparent digestibilities of nitrogen and fat but showed no significant effect on the apparent digestibility of fiber. This finding suggests that LB increased the chicks' ability to digest some nutrients (Apata, 2008). Gopal (2001) demonstrated that Lactobacillus strains can inhibit the adhesion to the intestinal wall of a range of pathogenic bacteria that compete for available nutrients. This action could produce an improvement in intestinal absorption and retention of nutrients, as evidenced in the increase in nitrogen and fat digestion for all LB treatment groups. This observation confirms previous findings (Zulkifli et al., 2000) that dietary supplementation with LB cultures improved the performance of chickens. The enhanced growth with LB may be partly attributed to the colonization of the gastrointestinal tract of the chicks with beneficial microorganisms, which improved the digestion of essential nutrients.

Adding whey to diet positively contributed to digestibility and absorption of nutrients in diet. This may be attributed to the fact that whey produces acidic condition that is suitable for growth of lactobacillus, thus increasing digestibility and absorption of nutrients (Bilgili and Moran, 1995). Much of the antimicrobial 
activity exhibited by probiotics may be attributed to the production of lactic acid (Makras et al., 2006). Lactic acid had been shown to be a potent agent involved in membrane permeability, thus causing sublethal membrane damage of E.coli (FayolMessaoudi et al., 2005). The mechanism behind the antimicrobial effects of lactate is attributed to lowering the internal $\mathrm{pH}$ of a bacterial cell through the dissociation of the organic acids (Alakomi et al., 2000).

\section{Economic Efficiency (EF):}

The final body weight and feeding cost are generally among the most important factors involved in achieving maximum efficiency of meat production. The effect of dietary treatments on economic efficiency is presented in Table (5). It should be pointed out that the economic efficiency values were calculated according to the prevailing market (selling) price of one-kilogram live body weight, which was 10.0 LE at the end of experimental period. Results indicated that when broiler chicks were fed diets that contained either commercial or natural probiotics, the average values of the total cost $/ \mathrm{kg}$ body weight decreased. The average values of total revenue, net revenue, economic efficiency, and relative economic efficiency were increased compared with control diet. Also, the data showed that adding both skimmed milk and whey to broiler chick diets improved average values of economic efficiency compared to either control diet or Avi-Bac supplemented diet. This finding is in agreement with that obtained by Abd-Elsamee (2001) who found that adding Avi-Bac as a probiotic to broiler chick diet improved economical efficiency.

In current study, the results showed that commercial (Avi-Bac) or natural (skimmed milk and whey) probiotics administration in feed with a certain concentration displayed a growth promoting effect, improved performance and nutrient digestibility. Based on these findings, addition of $1 \%$ whey in broiler diets is recommended to stimulate productive performance, nutrients digestibility and economical efficiency. However, the addition of probiotics to broilers, requires further research to clearly understand the mechanism of action among the added microorganisms, and to understand how the probiotics behave in the digestive tract of broilers.

\section{REFERENCES}

Abd-Elsamee, M.O., 2001. Broiler performance as affected by crude protein, lysine and a probiotic. Egypt. Poult. Sci., $21: 943-962$

Abou-Raya, A.K. and A.G.H. Galal, 1971. Evaluation of poultry feeds in digestion trials with reference to factors involved. Egypt. J. of Anim. Prod., 11: 207-221.

Aghaei, A., S. Tabatabaci, M. Chaji and M. Nazari, 2010. Effects of dried whey (probiotics) and probiotics in laying hen's performance and intestinal flora. J. of anim. and vet. Adv., 9 (15): 1996-2000.

Ahmad, I ., 2006. Effect of probiotics on broilers performance. Int. J. Poult. Sci., 5:593-597

Alakomi H.L., E. Skytta, M. Saarela, T. Mattila-Sandholm, and K. Latva-Kala, 2000. Lactic acid permeabilizes Gramnegative bacteria by disrupting the outer membrane. Appl . Environ. Microbiol., 66: 2001-2005

Al-Ubaidi, Y.Y. and H.R. Bird, 1964. Assay for the unidentified growth factor in dried whey. Poult. Sci., 43: 1848-1851.

A.O.A.C., 1990. Official methods of analysis. Association of Official Agricultural Chemists. $15^{\text {th }}$ ed. Washington, D.C.

Apata, D.F., 2008. Growth performance, nutrient digestibility and immune response of broiler chicks fed diets supplemented with a culture of Lactobacillus bulgaricus. J. Sci. Food Agric., 88:1253-1258 .

Awad, W.A., K. Ghareeb and J. Böhm, 2010. Effect of addition of a probiotic microorganism to broiler diets on intestinal mucosal architecture and electrophysiological parameters. Anim. Phys. and Anim. Nutr., 94: 486-494

Barteczko, J., 1997. The alternative in vitro method for estimation of fermentation processes in broilers. Zesz. Nauk. Przegl. Hod., 32: 217-223.

Barton, M.D., 2000. Antibiotic use in animal feed and its impact on human health. Nutrition Research Reviews. 13: 279-299.

Bielecka, M., W. Smoragiewicz, A.K. Siwicki, R. Wójcik, E. Biedrzycka, A. Orłowski, S. Kask, J. Jankowski, B. Karska-Wysocki, and D. Ham, 2010. The effect of various probiotic strains or avilamycin feed additive on immune defense markers and acute-phase response to salmonella infection in chickens. Probiotics \& Antimicro. Prot., 2: 175-185.

Bilgili, S.F. and E.T. Moran, 1995. Influence of whey and probiotics supplemented withdrawal feed on the retention of salmonella incubated into marked age broiler. Poult. Sci., 69: 1670-1674.

Cleaves, E.W. and A.A. Salim, 1982. The effect of lactose supplementation and source on feed intake and production 
characteristics of laying hens. Poult. Sci., 61: 2390-2397.

Duncan, D.B., 1955. Multiple range and multiple F-tests. Biometrics. 11: 1-42.

Fayol-Messaoudi, D., C.N. Berger, M.H. Coconnier-Polter, V. Lievin-Le Moal and A.L. Servin, 2005. pH-, Lactic acid-, and non-lactic acid-dependent activities of probiotic Lactobacilli against Salmonella enteric Serovar Typhimurium. Appl. Environ. Microbiol., 71: 6008-6013

Fuller, R., 1989. Probiotics in man and animals. J. Appl. Bacteriol., 66: 365-378

Gopal, P.K., 2001. In vitro adherence properties of Lactobacillus rhamnosus DR20 and Bifidobacterium lactis DR10 strains and their antagonistic activity against an enterotoxigenic Escherichia coli. Int. Food. Microbiol., 97: 207-216.

Gulsen, N., B. Coskun, H.D, Umucalilar, F. Inal, and M. Boydak, 2002. Effect of lactose and dried whey supplementation on growth performance and history of the immune system in broilers. Arch. Anim. Nutr., 56: 131-139

Jadamus, A., 2001. Untersuchungen zur Wirksamkeit und Wirkungsweise des sporebildenden Bacillus cereus var. toyoi im Verdauungstract von Broilern und Ferkel. PhD thesis, Free University, Berlin

Jakobsen, P.E., S.G. Kirston, and H. Nelson, 1960. Digestibility trials with poultry. 322 bertning fraforsgs laboratories, udgivet of stants Husdyrbugsudvalg-Kabenha

Jin, L.Z., H.W. Ho, N. Abdullah and S. Jalaludin, 1997. Probiotics in poultry: modes of action. World's Poult. Sci., 53: 352-368.

Jin, L.Z., Y.W. Ho, N. Abdullah and S. Jalaludin, 2000. Digestive and bacterial activities in broiler fed diets supplemented with lactobacillus culture. Poult. Sci., 79: 886-891

Kabir, S.M.L., 2009. The role of probiotics in the poultry industry. Int. J. Mol. Sci., 10: 3531-3546

Kermanshahi, H. and H. Rostami, 2006. Influence of supplemental dried whey on broiler performance and cecal flora. Int. J. Poult. Sci., 5: 538-543

Khakesfidi, A., and T. Ghoorchi, 2006. Effect of probiotic on performance and immunocompetence of broiler chicken. Poul. Sci., 43: 296-300.

Kim, J.S., S.L. Ingale, Y.W. Kim, K.H. Kim, S. Sen, M.H. Ryu, J.D. Lohakare, I. K. Kwon, and B.J. Chae, 2011. Effect of supplementation of multi-microbe probiotic product on growth performance, apparent digestibility, cecal microbiota and small intestinal morphology of broilers. J. of Anim. Phys. and Anim. Nutr., 95: 632-641

Li, L.L., Z.P. Hou, T.J. Li, G.Y. Wu, R.L. Huang, Z.R. Tang, C.B. Yang, J. Gong, H. $\mathrm{Yu}$, and X.F. Kong, 2008. Effects of dietary probiotic supplementation on ileal digestibility of nutrients and growth performance in 1 to 42 day-old broilers. J. of the Sci.of Food and Agri., 88: 35-42.

Majewska, T., K. Pudyszak, K. Kozłowski, K. Bohdziewicz and P. Matusevičius, 2009. Whey and lactic acid in broiler chickens nutrition. Veterinarija ir Zootechnika (Vet. Med. Zoot.). T. 47 (69): 56-59

Makras, L., V. Triantafyllou, D. FayolMessaoudi, T. Adriany, and G. Zoumpopoulou, 2006. Kinetic analysis of the antibacterial activity of probiotic lactobacilli towards Salmonella enterica serovar Typhimurium reveals a role for lactic acid and other inhibitory compounds. Res Microbiol., 157: 241-247

Maragkoudakis, P.A., G. Zoumpopoulou, C. Miaris, G. Kalantzopoulos, B. Pot, and E. Tsakalidou, 2006. Probiotic potential of Lactobacillus strains isolated from dairy products. Int. Dairy J. 16: 189-199.

Modler, H.W., 1982. The use of whey as animal feed and fertilizer. International Dairy federation. Brussels, Belgium.

Molnár, A.K., B. Podmaniczky, P. Kürti, R. Glávits, G. Virág, Z. Szabó and Z. Farkas, 2011. Effect of different concentrations of bacillus subtilis on immune response of broiler chickens. Probiotics \& Antimicro. Prot., 3: 8-14.

Morishita, Y., R. Fuller and M. Coates, 1982. Influence of dietary lactose on the gut flora of chicks. Br. Poult. Sci., 23: 349-356.

Mountzouris, K.C., P. Tsirtsikos, E. Kalamara, S. Nitsh, G. Schatzmayr and K. Fegeros, 2007. Evaluation of the efficacy of a probiotic containing Lactobacillus, Bifidobacterium, Enterococcus, and Pediococcus strains in promoting broiler performance and modulating caecal microflora composition and metabolic activities. Poult. Sci., 86: 309-317.

Mountzouris, K.C., P. Tsirtsikos, I. Palamidi, A. Arvaniti, M. Mohnl, G. Schatzmayr, and K. Fegeros, 2010. Effects of probiotic inclusion levels in broiler nutrition on growth performance, nutrient digestibility, plasma immunoglobulins, and caecal microflora composition. Poul. Sci., 89: 5867.

Mulder, R.W., R. Havenaar and J.H. Huis, 1997. Intervention strategies: the use of probiotics and competitive exclusion microfloras against contamination with pathogens in poultry and pigs, in Probiotics 2: Application and Practical Aspects, ed. 
by Fuller R. Chapman \& Hall, New York, pp. 187-207

National Research Council (NRC), 1994. Nutrient Requirements of Poultry. $9^{\text {th }}$ rev. ed. Natl. Acad. Press, Washington, DC.

Pijanowski, E., 1984. Zarys chemii i technologii mleczarstwa. Warszawa: PWRiL, P. 116-118

Priyankarage, N., S.S.P. Silva, S.P. Gunaratne, H. Kothalawala, M.W.C.D. Palliyaguru and G.A. Gunawardana, 2003. Efficacy of probiotics and their effects on performance, carcase characteristics, intestinal microflora and Salmonella incidence in broilers. Br. Poult. Sci., 44: S26-S27.

Radfar, M. and P. Farhoomand, 2008. The role of probiotic and source of lactose as feed additives on performance and gut improvement in broilers. Asian journal and veterinary advances. 3 : 179-182

Samli, H.E., N. Senkoylu, F. Koc, M. kanter and A. Agma, 2007. Effects of Entrerococcus faecium and dried whey on broiler performance, gut histomorphology and intestinal microbiota. Arch. of Anim. Nutr., 61: 42-49.

SAS institute, 2004. SAS/STAT User's Guide. SAS Institute Inc., Cary, NC.

Shariatmadari, F. and J.M. Forbes, 2005. Performance of broiler chickens given whey in the food and/or drinking water. Br. Poult. Sci., 46: 498-505.

Shim, Y.H., P.L. Shinde, J.Y. Choi, J.S. Kim, D.K. Seo, J.I. Pak, B.J. Chae, and I.K. Kwon, 2010. Evaluation of multimicrobial probiotics produced by submerged liquid and solid substrate fermentation methods in broilers. AsianAustr. J. of Anim. Sci., 23: 521-529

Sodini, I., A. Lucas, M.N. Oliveira, F. Remeuf and G. Corrieu, 2002. Effect of milk base and starter culture on acidification, texture, and probiotic cell counts in fermented milk processing. J. Dairy Sci., 85: 2479-2488

Susmel, P., M. Spanghoro, C.N. Mils and B. Stetanon, 1995. Rumen fermentation characteristics and digestibility of cattle diets containing different whey: maize ratios. Anim. Feed Sci. and Tec., 53: 81-88.

Taranto, M.P., G. Perez-Martinez and G.F. De Valdez, 2006. Effect of bile acid on the cell membrane functionality of lactic acid bacteria for oral administration. Res. Microbiol., 157: 720-725.

Tellez, G., C.E. Dean, D.E. Corrier, Jr. Deloach, L. Laeger and B.M. Harris, 1993. Effect of dietary lactose on cecal morphology, $\mathrm{pH}$, organic acids and salmonella emeritidis organ invasion in leghorn chickens. Poult. Sci., 72: 636-642

Thivend, P., 1977. Use of whey in feeding ruminants. With particular reference to pollution problems. World Anim. Rev., 23: 20-20.

Wang, Y. and Q. Gu, 2010. Effect of probiotic on growth performance and digestive enzyme activity of Arbor Acres broilers. Research in Veterinary Science. 89: 163167

Willis, W.L. and L. Reid, 2008. Investigating the effects of dietary probiotic feeding regimens on broiler chicken production and Campylobacter jejuni presence. Poult. Sci., 87: 606-611.

Zulkifli, I., N. Abdullah, M.N. Azrin and H. YW., 2000. Growth performance and immune response of two commercial broiler strains containing Lactobacillus cultures and oxytetracycline under heat stress conditions. Br. Poult. Sci., 41:593597. 
Table 1. Composition and calculated analysis of experimental grower diets (1-4 weeks)

\begin{tabular}{|c|c|c|c|c|c|c|}
\hline \multirow[t]{3}{*}{ Ingredients } & \multirow{2}{*}{$\begin{array}{c}\text { Control } \\
\mathbf{0 \%}\end{array}$} & \multirow{2}{*}{$\begin{array}{c}\text { Avi-Bac } \\
0.1 \% \\
\end{array}$} & \multicolumn{2}{|c|}{ Skimmed milk } & \multicolumn{2}{|c|}{ Whey } \\
\hline & & & $0.5 \%$ & $1 \%$ & $0.5 \%$ & $1 \%$ \\
\hline & $\mathbf{T}_{1}$ & $\mathbf{T}_{2}$ & $\mathbf{T}_{3}$ & $\mathbf{T}_{4}$ & $\mathbf{T}_{5}$ & $\mathbf{T}_{6}$ \\
\hline Yellow corn & 58.4 & 58.2 & 57.5 & 56.8 & 57.5 & 56.8 \\
\hline Soybean meal (48\% CP) & 27.0 & 27.0 & 27.0 & 27.0 & 27.0 & 27.0 \\
\hline Corn gluten $(60 \% \mathrm{CP})$ & 8.0 & 8.0 & 8.0 & 8.0 & 8.0 & 8.0 \\
\hline Vegetable oil & 2.0 & 2.1 & 2.4 & 2.6 & 2.4 & 2.6 \\
\hline Di-Ca Phosphate & 2.0 & 2.0 & 2.0 & 2.0 & 2.0 & 2.0 \\
\hline Limestone & 1.5 & 1.5 & 1.5 & 1.5 & 1.5 & 1.5 \\
\hline $\mathrm{NaCl}$ & 0.3 & 0.3 & 0.3 & 0.3 & 0.3 & 0.3 \\
\hline Vit. \& min. premix * & 0.4 & 0.4 & 0.4 & 0.4 & 0.4 & 0.4 \\
\hline DL-methionine & 0.1 & 0.1 & 0.1 & 0.1 & 0.1 & 0.1 \\
\hline L-lysine HCl & 0.2 & 0.2 & 0.2 & 0.2 & 0.2 & 0.2 \\
\hline Anticoccidia & 0.1 & 0.1 & 0.1 & 0.1 & 0.1 & 0.1 \\
\hline Avi-Bac & - & 0.1 & - & - & - & - \\
\hline Skimmed milk & - & - & 0.5 & 1.0 & - & - \\
\hline Whey & - & - & - & - & 0.5 & 1.0 \\
\hline Total & 100.0 & 100.0 & 100.0 & 100.0 & 100.0 & 100.0 \\
\hline \multicolumn{7}{|l|}{ Calculated analysis** } \\
\hline CP \% & 23.10 & 23.12 & 23.06 & 23.01 & 23.06 & 23.01 \\
\hline ME kcal/ kg & 3102 & 3103 & 3106 & 3101 & 3106 & 3101 \\
\hline EE \% & 4.82 & 4.92 & 5.19 & 5.36 & 5.19 & 5.36 \\
\hline CF \% & 3.41 & 3.41 & 3.39 & 3.38 & 3.39 & 3.38 \\
\hline $\mathrm{Ca} \%$ & 1.07 & 1.07 & 1.07 & 1.07 & 1.07 & 1.07 \\
\hline Available Phosphorus \% & 0.49 & 0.49 & 0.49 & 0.49 & 0.49 & 0.49 \\
\hline Methionine \% & 0.56 & 0.56 & 0.56 & 0.56 & 0.56 & 0.56 \\
\hline Methionine + cysteine \% & 0.71 & 0.71 & 0.71 & 0.71 & 0.71 & 0.71 \\
\hline Lysine \% & 1.26 & 1.26 & 1.26 & 1.26 & 1.26 & 1.26 \\
\hline Price / ton (LE) & 2520 & 2550 & 2530 & 2530 & 2530 & 2530 \\
\hline
\end{tabular}


Table 2. Composition and calculated analysis of experimental finisher diets (5-6 weeks)

\begin{tabular}{|c|c|c|c|c|c|c|}
\hline \multirow{3}{*}{ Ingredients } & \multirow{2}{*}{$\begin{array}{c}\text { Control } \\
\mathbf{0 \%} \\
\end{array}$} & \multirow{2}{*}{$\begin{array}{c}\text { Avi-Bac } \\
0.1 \% \\
\end{array}$} & \multicolumn{2}{|c|}{ Skimmed milk } & \multicolumn{2}{|c|}{ Whey } \\
\hline & & & $0.5 \%$ & $1 \%$ & $0.5 \%$ & $1 \%$ \\
\hline & $\mathbf{T}_{1}$ & $\mathbf{T}_{2}$ & $\mathbf{T}_{3}$ & $\mathbf{T}_{4}$ & $\mathbf{T}_{5}$ & $\mathbf{T}_{6}$ \\
\hline Yellow corn & 66.2 & 66.0 & 65.3 & 64.5 & 65.3 & 64.6 \\
\hline Soybean meal $(48 \% \mathrm{CP})$ & 20.0 & 20.0 & 20.0 & 20.0 & 20.0 & 20.0 \\
\hline Corn gluten $(60 \% \mathrm{CP})$ & 7.5 & 7.5 & 7.5 & 7.5 & 7.5 & 7.5 \\
\hline Vegetable oil & 2.3 & 2.4 & 2.7 & 3.0 & 2.7 & 2.9 \\
\hline Di-Ca Phosphate & 2.0 & 2.0 & 2.0 & 2.0 & 2.0 & 2.0 \\
\hline Limestone & 1.0 & 1.0 & 1.0 & 1.0 & 1.0 & 1.0 \\
\hline $\mathrm{NaCl}$ & 0.3 & 0.3 & 0.3 & 0.3 & 0.3 & 0.3 \\
\hline Vit. \& min. premix * & 0.4 & 0.4 & 0.4 & 0.4 & 0.4 & 0.4 \\
\hline DL-methionine & 0.1 & 0.1 & 0.1 & 0.1 & 0.1 & 0.1 \\
\hline L-lysine HCl & 0.2 & 0.2 & 0.2 & 0.2 & 0.2 & 0.2 \\
\hline Avi-Bac & - & 0.1 & - & - & - & - \\
\hline Skimmed milk & - & - & 0.5 & 1.0 & - & - \\
\hline Whey & - & - & - & - & 0.5 & 1.0 \\
\hline Total & 100.0 & 100.0 & 100.0 & 100.0 & 100.0 & 100.0 \\
\hline \multicolumn{7}{|l|}{ Calculated analysis** } \\
\hline СР \% & 20.17 & 20.15 & 20.09 & 20.02 & 20.09 & 20.02 \\
\hline ME kcal/ kg & 3200 & 3202 & 3204 & 3204 & 3204 & 3204 \\
\hline EE \% & 5.30 & 5.39 & 5.67 & 5.94 & 5.67 & 5.94 \\
\hline CF \% & 3.07 & 3.06 & 3.05 & 3.03 & 3.05 & 3.03 \\
\hline Ca \% & 0.87 & 0.87 & 0.87 & 0.87 & 0.87 & 0.87 \\
\hline Available Phosphorus \% & 0.47 & 0.47 & 0.47 & 0.47 & 0.47 & 0.47 \\
\hline Methionine \% & 0.51 & 0.51 & 0.51 & 0.51 & 0.51 & 0.51 \\
\hline Methionine + cysteine \% & 0.64 & 0.64 & 0.64 & 0.64 & 0.64 & 0.64 \\
\hline Lysine \% & 1.07 & 1.07 & 1.07 & 1.07 & 1.07 & 1.07 \\
\hline Price / ton (LE) & 2440 & 2470 & 2450 & 2450 & 2450 & 2450 \\
\hline
\end{tabular}


Table 3. Effect of dietary treatments on broiler performance

\begin{tabular}{|c|c|c|c|c|c|c|c|c|}
\hline \multirow[t]{3}{*}{ Item } & \multirow{2}{*}{$\begin{array}{c}\text { Control } \\
\mathbf{0 \%}\end{array}$} & \multirow{2}{*}{$\begin{array}{c}\text { Avi-Bac } \\
0.1 \%\end{array}$} & \multicolumn{2}{|c|}{ Skimmed milk } & \multicolumn{2}{|c|}{ Whey } & \multirow{3}{*}{ \pm SEM } & \multirow{3}{*}{$\begin{array}{c}\text { P- } \\
\text { Value }\end{array}$} \\
\hline & & & $0.5 \%$ & $1 \%$ & $0.5 \%$ & $1 \%$ & & \\
\hline & $\mathbf{T}_{1}$ & $\mathbf{T}_{2}$ & $\mathbf{T}_{3}$ & $\mathbf{T}_{4}$ & $\mathbf{T}_{5}$ & $\mathbf{T}_{6}$ & & \\
\hline
\end{tabular}

\section{Body weight (g)}

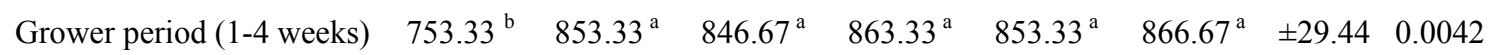

Finisher period (5-6 weeks) $1620.00^{\mathrm{c}} \quad 1743.33^{\mathrm{b}} 1750.00^{\mathrm{b}} \quad 1790.00^{\mathrm{b}} 1756.67^{\mathrm{b}} \quad 1860.00^{\mathrm{a}} \pm 33.58<0.0001$

\section{Body weight gain (g)}

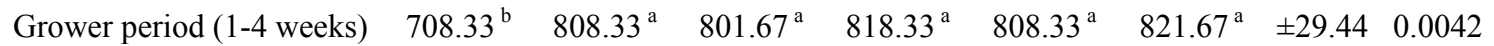

Finisher period (5-6 weeks) $\quad 866.67^{\mathrm{d}} \quad 890.00^{\mathrm{cd}} \quad 903.33^{\mathrm{bc}} \quad 926.67^{\mathrm{b}} \quad 903.33^{\mathrm{bc}} \quad 993.33^{\mathrm{a}} \quad \pm 13.33<0.0001$

Overall period (1-6 weeks) $1575.00^{\mathrm{c}} 1698.33^{\mathrm{b}} 1705.00^{\mathrm{b}} 1745.00^{\mathrm{b}} 1711.67^{\mathrm{b}} 1815.00^{\mathrm{a}} \pm 33.58<0.0001$

Feed intake (g/bird)

Grower period (1-4 weeks) $\quad 1516.67^{\mathrm{b}} \quad 1553.33^{\mathrm{ab}} \quad 1586.67^{\mathrm{a}} \quad 1590.00^{\mathrm{a}} \quad 1536.67^{\mathrm{ab}} 1573.33^{\mathrm{ab}} \pm 31.00 \quad 0.0469$

Finisher period (5-6 weeks) $2060.00^{\mathrm{d}} 2090.00^{\mathrm{cd}} 2133.33^{\mathrm{bc}} 2186.67^{\mathrm{b}} 2120.00^{\mathrm{c}} \quad 2263.33^{\mathrm{a}} \pm 30.28<0.0001$

Overall period 1-6 weeks $\quad 3576.67^{\mathrm{d}} 3643.33^{\text {cd }} 3720.00^{\text {bc }} 3776.67^{\text {ab }} 3656.67^{\text {cd }} 3836.66^{\text {a }} \pm 47.20 \quad 0.0002$

Feed conversion ratio (g.feed / g.gain)

Grower period (1-4 weeks) $\quad 2.14^{\mathrm{a}} \quad 1.92^{\mathrm{b}} \quad 1.98^{\mathrm{b}} \quad 1.94^{\mathrm{b}} \quad 1.90^{\mathrm{b}} \quad 1.92^{\mathrm{b}} \quad \pm 0.045 \quad 0.0003$

Finisher period (5-6 weeks) $\quad 2.38^{\mathrm{a}} \quad 2.35^{\mathrm{a}} \quad 2.36^{\mathrm{a}} \quad 2.36^{\mathrm{a}} \quad 2.35^{\mathrm{a}} \quad 2.28^{\mathrm{b}} \quad \pm 0.027 \quad 0.0126$

Overall period 1-6 weeks $\quad 2.27^{\mathrm{a}} \quad 2.15^{\mathrm{bc}} \quad 2.18^{\mathrm{b}} \quad 2.16^{\mathrm{bc}} \quad 2.14^{\mathrm{bc}} \quad 2.11^{\mathrm{c}} \quad \pm 0.030 \quad 0.0005$

The mean values with different small letters $(a, b, c, \ldots$ etc. $)$ within the same row indicate significant differences $(\mathrm{P} \leq 0.05)$.

Table 4. Effect of dietary treatments on nutrients digestibility

\begin{tabular}{|c|c|c|c|c|c|c|c|c|}
\hline \multirow[t]{3}{*}{ Item } & \multirow{2}{*}{$\begin{array}{c}\text { Control } \\
\mathbf{0 \%}\end{array}$} & \multirow{2}{*}{$\begin{array}{c}\text { Avi-Bac } \\
0.1 \%\end{array}$} & \multicolumn{2}{|c|}{ Skimmed milk } & \multicolumn{2}{|c|}{ Whey } & \multirow[t]{3}{*}{ \pm SEM } & \multirow[t]{3}{*}{ P-Value } \\
\hline & & & $0.5 \%$ & $1 \%$ & $0.5 \%$ & $1 \%$ & & \\
\hline & $\mathbf{T}_{1}$ & $\mathbf{T}_{2}$ & $\mathbf{T}_{3}$ & $\mathbf{T}_{4}$ & $\mathbf{T}_{5}$ & $\mathbf{T}_{6}$ & & \\
\hline OM & $82.27^{b}$ & $83.03^{a b}$ & $79.90^{\mathrm{c}}$ & $80.50^{c}$ & $78.23^{d}$ & $83.43^{\mathrm{a}}$ & \pm 0.554 & $<0.0001$ \\
\hline $\mathrm{CP}$ & $87.63^{e}$ & $90.83^{a b}$ & $90.10^{b c}$ & $89.83^{c}$ & $88.80^{\mathrm{d}}$ & $91.27^{\mathrm{a}}$ & \pm 0.457 & $<0.0001$ \\
\hline EE & $75.60^{b}$ & $76.27^{\mathrm{b}}$ & $73.77^{d}$ & $73.40^{d}$ & $74.63^{c}$ & $77.10^{\mathrm{a}}$ & \pm 0.453 & $<0.0001$ \\
\hline CF & 30.80 & 30.63 & 30.27 & 29.87 & 29.83 & 30.90 & \pm 0.478 & 0.0639 \\
\hline NFE & $80.90^{\mathrm{a}}$ & $81.17^{\mathrm{a}}$ & $79.73^{b}$ & $79.47^{b c}$ & $78.73^{c}$ & $81.13^{\mathrm{a}}$ & \pm 0.524 & 0.0003 \\
\hline NB & $62.33^{c}$ & $64.33^{\mathrm{b}}$ & $62.30^{\mathrm{c}}$ & $62.27^{\mathrm{c}}$ & $63.57^{\mathrm{b}}$ & $66.13^{\mathrm{a}}$ & \pm 0.439 & $<0.0001$ \\
\hline
\end{tabular}

The mean values with different small letters (a, b, c,...etc.) within the same row indicate significant differences $(\mathrm{P} \leq 0.05)$. 
Egyptian J. Anim. Prod. (2012)

Table 5. Effect of dietary treatments on economical efficiency of the experimental diets

\begin{tabular}{|c|c|c|c|c|c|c|}
\hline \multirow[t]{3}{*}{ Item } & \multirow{2}{*}{$\begin{array}{c}\text { Control } \\
\mathbf{0 \%}\end{array}$} & \multirow{2}{*}{$\begin{array}{c}\text { Avi-Bac } \\
0.1 \%\end{array}$} & \multicolumn{2}{|c|}{ Skimmed milk } & \multicolumn{2}{|c|}{ Whey } \\
\hline & & & $0.5 \%$ & $1 \%$ & $0.5 \%$ & $1 \%$ \\
\hline & $\mathbf{T}_{1}$ & $\mathbf{T}_{2}$ & $\mathbf{T}_{3}$ & $\mathbf{T}_{4}$ & $\mathbf{T}_{5}$ & $\mathbf{T}_{6}$ \\
\hline Fixed cost $(\mathrm{LE})^{\mathrm{a}}$ & 5.50 & 5.50 & 5.50 & 5.50 & 5.50 & 5.50 \\
\hline Feed cost (LE) & 8.85 & 9.12 & 9.25 & 9.38 & 9.08 & 9.52 \\
\hline Total cost (LE) & 14.35 & 14.62 & 14.75 & 14.88 & 14.58 & 15.02 \\
\hline Body weight (kg) & 1.57 & 1.69 & 1.71 & 1.75 & 1.71 & 1.82 \\
\hline Cost/kg body weight (LE) & 9.14 & 8.65 & 8.63 & 8.50 & 8.53 & 8.25 \\
\hline Total revenue $(\mathrm{LE})^{\mathrm{b}}$ & 15.70 & 16.90 & 17.10 & 17.50 & 17.10 & 18.20 \\
\hline Net revenue $(\mathrm{LE})^{\mathrm{c}}$ & 1.35 & 2.28 & 2.35 & 2.62 & 2.52 & 3.18 \\
\hline Economic efficiency (EF) & 0.094 & 0.156 & 0.159 & 0.176 & 0.173 & 0.212 \\
\hline $\begin{array}{l}\text { Relative economic efficiency } \\
(\text { REF })^{d}\end{array}$ & 100 & 166 & 169 & 187 & 184 & 225 \\
\hline
\end{tabular}

a) Bird price and rearing cost.

b) Assuming that the selling price of one kg. body weight is $10.0 \mathrm{LE}$.

c) Net revenue per unit total cost $=$ total revenue - total cost.

d) Assuming that the treatment number 1 represent the control 100\%.

\section{القيمة الغذائية للبن الفرز و شرش اللبن والمضافة كمنشطات حيوية طبيعة فى علاثق دجاج اللحم}

إسلام إبراهيم عماره

قسم الإنتاج الحيوانس، كلية الزراعة ، جامعة القاهرة

الجريت هذه التجربة لدراسة تأثثر إضافة المنشطات الحيوية سواء كانت تجارية أو طبيعية إلى علائق دجاج اللحم على الأداء

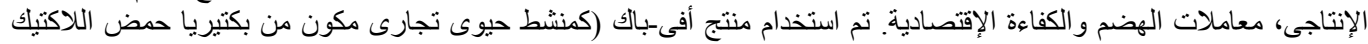

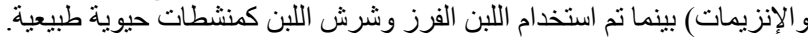

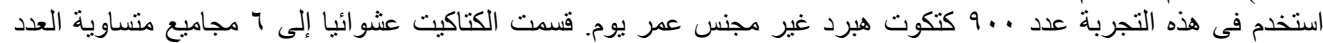

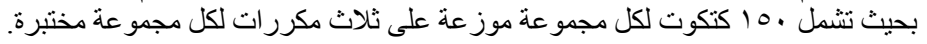

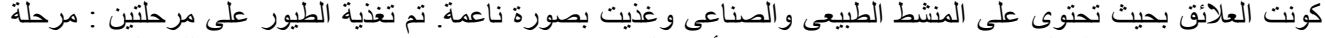

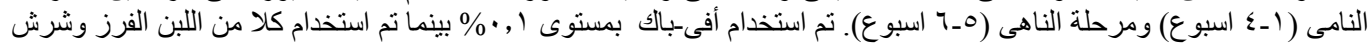

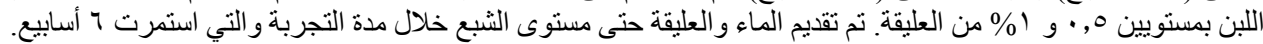

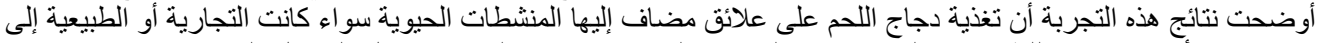

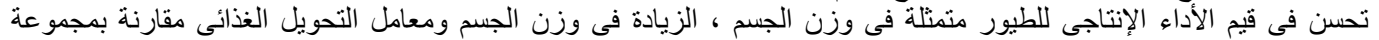

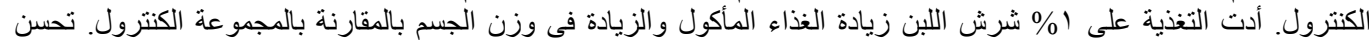

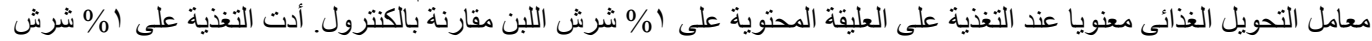

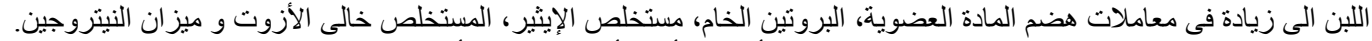

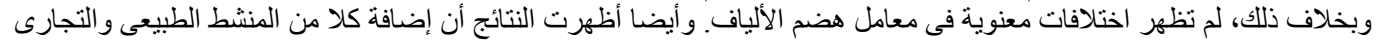

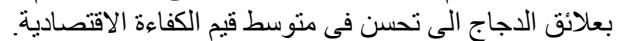

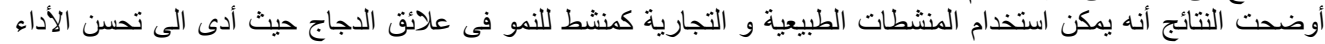
الانتاجى ، معاملات الهضم و الكفاءة الاقتصادية للاجاج. 